\title{
Investigating the Key Factors Influencing on Management Information Systems Adoption among Telecommunication Companies in Yemen: The Conceptual Framework Development
}

\author{
Yaser Hasan Al-Mamary, Alina Shamsuddin and Nor Aziati \\ Universiti Tun Hussein Onn Malaysia, Faculty of Technology Management and \\ Business, 86400 Malaysia \\ Yaser_almamary@yahoo.com
}

\begin{abstract}
Organizations invest in information technology and systems because they provide economic value to the business. While recognizing the importance of the management information systems in the organization, the majority of Arab countries in Middle East and underdeveloped countries are still dealing with issues in adopting the technologies. Research in technology adoption among the Middle East countries more focused on internet banking, e-government and e-commerce area. Notwithstanding that individuals in the Middle East are known as late adopter, organizations in Middle East are unable to infuse management system into their business processes. To fully adopt the management information systems, organization must understand the three dimensions of information system; organization, people and technology itself. Thus, this study aims to shed some light on the management information systems adoption among the employees at telecommunication companies in Yemen. The study of the country is still inadequate and less exposure. Hence, the purpose of this study is to provide a conceptual framework for analyzing the factors affecting management information systems adoption. As the organization responsible for providing internet and mobile phones, telecommunication companies should be the first to adopt the latest technology in the market to better provide good infrastructures. In accordance, this study may help managers and policy makers identify the factors in their effort to attract more employees and to adopt the management information systems in the organization.
\end{abstract}

Keywords: Key Factors; Management Information System Adoption; Telecommunication Sector, TOP Model ( Technological, Organizational, and People Model )

\section{Introduction}

In the era of digitalization, data have become one of the most important resources to organizations. Earlier, manual system is used for collecting, processing and storing the information. Today the organizations stored huge amount of information especially for multinational companies. In some cases, organizations store information for more than one million customers, hence; the legacy system is no longer feasible. As a result of the internet and technological revolution, information systems (IS) have become very important in all fields, especially in the field of management. According to [1], for the last twenty years, different kinds of information systems are developed for different purposes, depending on the need of the business. Each plays a different role in organizational hierarchy and management operations [2].

According to [3] Management information system one of the most important tools in any organization, which aims to provide reliable, complete, accessible, and understandable information in a timely manner to the users of the system. According to 
[4] Management information systems one of the most important achievements in the area of administrative work, which aims to provide reliable, accurate, relevant and complete information to managers toward enhancing of organizational performance in organizations.

Management information system serves the management level of the organization, providing managers with reports or with on-line access to the organization's current performance and historical records. Typically, they are oriented almost exclusively to internal, not environmental or external events. Management information system primarily serve the functions of planning, controlling, and decision making at the management level. With the advances of latest technologies in telecommunication, management information system plays vital roles to ensure that telecommunication companies can be more competitive. Competitive telecommunications companies in Yemen are beginning to see the need to move from legacy systems to high-capacity systems and technology to meet the changing digital society. Yemen is known as one of the least developed countries among the other Middle East countries. Due to some constraints such as economic sanctions and political unrest, low ICT budget, lack of qualified human resource and high illiteracy among citizens resulting in the slow penetration of Internet. Yemen has achieved the lowest telecommunication and online services index when compared with countries such as Oman, the Maldives and Bahrain.

Several researchers from Yemen were discussing issues related to technology adoption in the country.

Based on preliminary interviews with some of the employees of telecommunications companies in Yemen, the main problem hinder the successful adoption of management information system in telecommunication companies are system quality, information quality, service quality, top management support, user training, computer self-efficacy, and user experience. From the issues mentioned earlier, this study will empirically examine the impact of these on perceived usefulness and user satisfaction toward impact on organizational performance. In addition there are some of the problems harassing the country is the lack of skilled manpower in handling IT based projects, low budget, lack of commitment from the top level management and little consideration or priority given to the IT development project in the company. Employees were given inadequate training because of the budget constraint. This situation will indirectly cause employees less vulnerable to the latest technologies as well as the lack of technical skills. Experiences working on technologies and systems greatly affect the ability of employees to learn a new technology even adopting the system. Based on the above problems, this study identified several factors associated with technology adoption issues, particularly in the context of Yemen. Moreover these studies seek to understand how the different factors that affect management information system adoption among Telecommunication Companies in Yemen.

\section{Telecommunication Sector in Yemen}

The telecommunications sector in Yemen is one of the most important sectors that contribute to the country GDP. According to the Yemeni Minister of Communications report, the total revenue 2013 of telecommunications sector in Yemen amounting to almost 400 million dollars. While the budget amounted to Yemen in 2013 is nearly to 12.9 billion dollars. In general, Yemen's telecommunications sector has shown improvement especially for fixed line subscriptions and Internet usage. Yet, it is considered as low with penetration rates of less than 3\% when compared with other Arab countries around Yemen. Given that $65 \%$ of the Yemeni population live in rural areas, there are significant amount of budget has been made by the telecommunication companies. The allocated budget for telecommunication sector is equivalent to nearly $2.8 \%$ of the overall budget of Yemen. This budget is among the lowest allocation provided by the Yemeni 
government against Middle East countries. There are four well-known mobile companies in Yemen namely; Sabafon, HiTS-UNITEL (Y), Spacetel Yemen (MTN), and Yemen mobile. Additionally, there is single provider of international telecommunications for Yemen-fixed-line, telex, and an Internet service is called Tele-Yemen. Tele-Yemen is a public private company jointly owned by the British Company Cable And Wireless PLC and the Public Telecommunications Corporation with responsibility for operating and developing international telecommunication services, mobile telephony services using TACS, and Internet and e-mail services. Basically, the services provided by the telecommunication can be classified into four types, namely information, communication, transaction, and entertainment. The telecom industry is an interesting industry to study due to high growth rate of this industry over the past few decades in Yemen compare the other sector.

In case of telecommunication companies the successful adoption of management information system will affect on organizational performance (improved labour productivity, improved the management of my work, reduces costs., helped to meet customer needs, providing the information without any delays and mistakes, and increases customer service/satisfaction) thus, the revenues of these companies will increase and will have a positive role in improving the country's economy.

In this era, management information system play important roles to the telecommunication companies especially for customer relationship management, HR management, billing and monitoring system. The main challenges of these days are to search for new cost effective ways to roll out telecom services in rural areas. This means that the company has to choose proper and effective technology for deployment and leverage on the use of available infrastructure to reduce cost and time of role out of services. Previous studies have listed some of the key factors in the adaptation of information systems, among which are: technological factors, organizational factors, cultural factors and human factors. Based on previous studies on technology adoption in Yemen, there are only three factors often discussed in the context of Yemen; technological factors, organizational factors and people factors. Thus, this study will analyze these factors and integrate these factors based on the theory of information systems success, and technology adoption.

\section{Theoretical Lens}

There are many adoption behaviour models/theories being developed in the IS research disciplines which consider technological, environmental and organizational factors as important predictor of individual technology adoption. This study seek to understand the impact of different factors discussed by previous researchers from the lens of Middle East countries that affect IS adoption in Yemeni telecommunication companies that significantly improved organizational performance. There are various theories being adapted in the context of technology adoption. Among the dominant theories come from the field of Information System are Innovation Diffusion Theory (IDT), Theory of reasoned action (TRA), Technology Acceptance Model (TAM), DeLone and McLean IS success model, Theory of planned behaviour (TPB), Unified theory of user acceptance of technology (UTAUT), Diffusion of innovation theory (DOI), TechnologyOrganization-Environment framework (TOE), computer usage model and personal computing acceptance model. IDT was one of the earliest theories used to examine technology adoption.

Theories have been used to support and justify the implementation of IS in the organization. As mentioned by past scholars, the successful adoption of technology in any companies is much depending on technology, project, organization, user, social, and task characteristics [5]. However, in reality these factors are much 
neglected by organizations especially among small companies. Despite the facts that different organization has different issues hindering the adoption of IS, Arabic such as Yemen; have tried to overcome the problems align with current technology. Thus, for this study, the selected theory is compatible with the Yemen's problems based on the factors identified in the literature. In reality, Yemen country still using legacy systems even half of the company's management is still done manually. The research shows lack of a successful; locally based IS adoption model for the organizations to emulate. Hence, the study proposed conceptual framework by combining four main theories; TAM, IS success model, personal computing model and computer usage model for the development an integrated model of IS adoption from the Yemeni context.

\section{Technological Factors}

\subsection{System Quality}

System quality is the desirable characteristics of any information system. The common measures for system quality that used/adopted by previous researchers are ease of use, flexibility, response time and reliability [6].

\subsection{Information Quality}

Information quality is the desirable characteristics of the system outputs. According to Al-Mamary et al., [7] A number of researchers consider information quality as important factor to MIS success in organization. For example relevance, understand ability, accuracy, conciseness, completeness, currency, timeliness, usability [8].

\subsection{Service Quality}

Service quality is the quality of the support that system users receive from the IS department and IT support personnel. For example; responsiveness, accuracy, reliability, technical competence, and empathy of the personnel staff $[9 ; 8]$.

\section{Organizational Factors}

\subsection{Top Management Support}

Top management support is able to ensure sufficient allocation of resources and act as a change agent to create a more conducive environment for IS success. For example: management is aware of the benefits that can be achieved with the use of the system, management always supports and encourages the use of the system for job-related work, management provides most of the necessary help and resources to enable people to use the system, management is really keen to see that people are happy with using the system, management provides good access to hardware resources when people need them, and management provides good access to various types of software when people need them [10].

\subsection{User Training}

Training is teaching the skills that needed to use Information Systems. Training is essential in the adoption of the systems. Quite often top management or IT department are asking employee to use specific software but do not provide adequate training. Therefore, sometimes the systems implementation is proved to be a failure because people do not have the right skills [11]. According to Igbaria et al., [10] the items that used to measure training are: the company offers training to use the system, the company offers internal 
training the company offers external training, the company offers training to use spreadsheets the company offers training to use word processing, the company offers training to use application packages, and the company offers training to use operation systems.

\section{People Factors}

\subsection{Computer Self-Efficacy}

Computer self-efficacy refers to an individual's belief that he or she has the skills and abilities to accomplish a specific task successfully [12]. According to Brown [13] the items that used to measure self-efficacy are: I feel comfortable using the system on my own, I can easily use any of the functions in the system, I be able to use the system even if there is no one around to show me how to use it (I can use the system without help from others).

\subsection{User Experience}

According to Chuttur [14] Experience is prior experience of an individual with a specific technology. According to Sabherwal [15] Experience is duration or level of an individual's prior use of computers and ISs. According to Igbaria1 and Iivari [16] the items that used to measure user experience are: I have experience in using the systems, I have experience in using spreadsheet, I have experience in using word processing, I participation in feasibility studies, I participation in requirements analysis, I have experience in using financial modelling, I have experience in using programming languages, and I participation in design of computerized information systems

\section{Perceived Usefulness and User Satisfaction}

Perceived usefulness is defined as the degree to which a person believes that using the new technology will enhance their task performance [17]. According to Davis [18] the items that used to measure perceived usefulness are: using the system in my job enables me to accomplish tasks more quickly, using the system improves my job performance, using the system in my job increases my productivity, using the system enhance my effectiveness on the job, using the system makes it easier to do my job, and overall, i find the system useful to my job.

According to su et al., [19] User satisfaction is measuring the consequences of users' response by using the output information of system. According to Petter [5] User satisfaction is Users' level of satisfaction with the IS. According to Halawi [20] user satisfaction refers to the recipient response to the use of the output of IS. According to Seddon [21] the items that used to measure user satisfaction are: the system meets our needs, satisfied with the system efficiency, satisfied with the system effectiveness, overall, we satisfied with the system. According to Palvia [22] the items that used to measure user satisfaction are: the system is successful, and the system meets our expectations.

\section{Organizational Performance Impact}

Organizational impact refers to the effect of IT on organizational performance [20]. Organizational performance is accumulated end results of all the organization's work processes and activities. There are a lot of measures for the organizational impact and these measures differ from one researcher to another. 


\section{Impact of IS Adoption on Organizational Performance}

Information Systems play a strategic role in the life of organizations, it provides the management with appropriate information and in the right place and time to help the management to do various functions of planning, organizing, directing and control and decision-making [23]. Every business organization in this era needs information system to keep track of all business activities [24]. IS transform data to information and summarized the information to meaningful and useful forms as management reports to use it in managerial decision making and support management activities [6]. Today's systems directly affect how managers decide, plan, and manage their employees, and, increasingly, they shape what products are produced, and where, when, and how. Therefore, responsibility for systems cannot be delegated to technical decision makers [1]. Businesses make use of management information systems so that accurate and up-to-date information will be available when it is required. Since it is not always possible to predict what information will be needed at some future date, most organizations use computers to record and store the details of all their business transactions. When a query arises, or a standard business report must be produced, this raw data can be retrieved and manipulated to produce the required information.

\section{TOP Model (Technological, Organizational, and People Model ) and Hypotheses Developments}

Based on the discussion above, this study combines theory with factors that have been identified to test the technology adoption in context telecommunications companies of Yemen. Accordingly, this study lists 9 main hypotheses to measure the impact of each factor on the performance of the organization. The combined hypotheses will form integrated model as shown in Figure. 1.

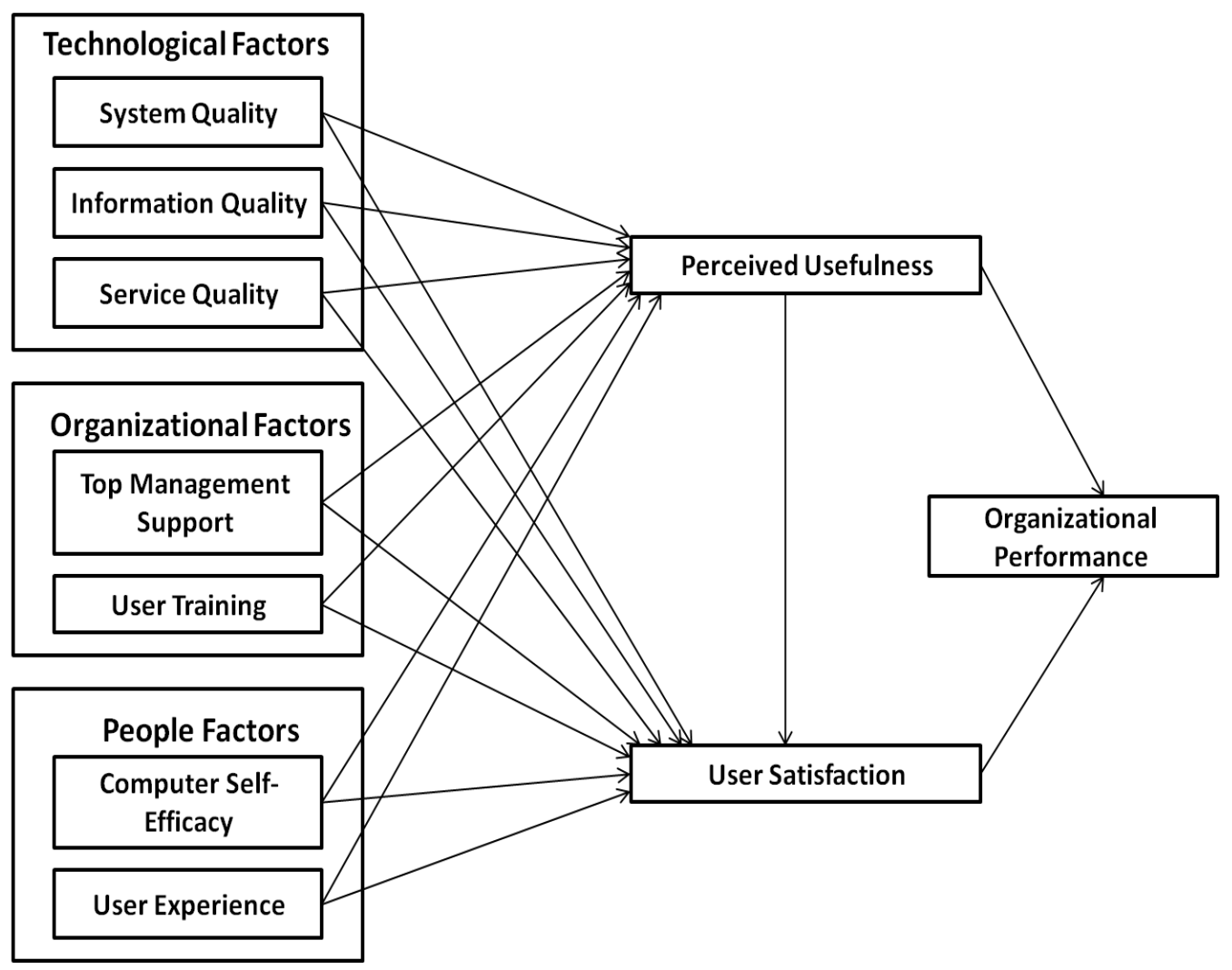

Figure 1. TOP Model ( Technological, Organizational, and People Model) 


\section{The proposed hypotheses are:}

H1a: There is positive relationship between System Quality and Perceived Usefulness.

H1b: There is positive relationship between System Quality and User Satisfaction.

H2a: There is positive relationship between Information Quality and Perceived Usefulness.

$\mathrm{H} 2 \mathrm{~b}$ : There is positive relationship between Information Quality and User Satisfaction.

H3a: There is positive relationship between Service Quality and Perceived Usefulness

H3b: There is positive relationship between Service Quality and User Satisfaction.

H4a: There is positive relationship between Top Management Support and Perceived Usefulness.

H4b: There is positive relationship between Top Management Support and User Satisfaction.

H5a: There is positive relationship between End-User Training and Perceived Usefulness.

H5b: There is positive relationship between End-User Training and User Satisfaction.

H6a: There is positive relationship between Technology Self-Efficacy and Perceived Usefulness.

H6b: There is positive relationship between Technology Self-Efficacy and User Satisfaction.

H7a: There is positive relationship between User Experience and Perceived usefulness.

H7b: There is positive relationship between User Experience and User Satisfaction.

H8a: There is positive relationship between Perceived usefulness and User Satisfaction.

H8b: There is positive relationship between Perceived Usefulness and Organizational Performance.

H9: There is positive relationship between User Satisfaction and Organizational Performance.

\section{Methodology}

\subsection{Research Population / Sample}

The population for this research are the employees in telecommunication companies in capital of Yemen (Sana'a) .

The sample size for this study will be group of employees in telecommunication companies that used the information systems in four companies namely as: MTN, Sabafon, Yemen mobile, and Y.

\subsection{Data Collection and Measures}

To achieve the objectives of the study, the data will collect through a questionnaire. The questionnaire was prepared on the basis of review of literature and many discussions with professionals and academicians.

All items will measured using a seven-point Likert scale from strongly agree to strongly disagree ( 1. Strongly agree,2. Agree,3. Somewhat agree, 4. Neither agree or disagree, 5. Somewhat disagree,6. Disagree, 7. Strongly disagree).

\subsection{Data Analysis}

Data will be analyzed quantitatively using the appropriate descriptive analysis for the distribution of population and demographic while validate to model using structural equation modeling techniques.

\subsection{Expected Results of The Study}

It is expected that the results will be develop model for successful adoption of IS in Telecommunication companies in Yemen. 


\section{Conclusion}

In summary, the proposed conceptual framework for this study, as depicted in Figure 1 comprises a combination of four theories:

- The Technology Acceptance Model.

- D\&M IS Success model.

- Computer Usage model.

- Personal Computing Acceptance Model.

Overall, the conceptual model consists of seven independent variables: IS quality, information quality, service quality, top management support, end-user training, computer self-efficacy, two mediating variables; perceived usefulness and user satisfaction, and one dependent variable; organizational performance. The variables were chosen based on relevance to the Yemen country. Through this model, the telecommunications companies in Yemen are able to enhance levels of technology adoption in particular the use of quality systems in the organization to ensure the companies and economic growth despite the various issues that plagued the country.

\section{Acknowledgements}

The authors would like to thank Faculty of Technology Management and Business UTHM for help. In addition thank ministry of Higher Education and Scientific Research in Yemen for support.

\section{References}

[1] Laudon, K. \& Laudon, J. (2006) Management Information Systems: Managing the Digital Firm, 9th ed. Prentice Hall.

[2] Al-Mamary ,Y. , \& Shamsuddin,A., \& Aziati ,N. (2014), The Role of Different Types of Information Systems in Business Organizations : A Review, International Journal of Research ,Vol.1, Issue.7,pp.333-339.

[3] Al-Mamary ,Y. , \& Shamsuddin,A., \& Aziati ,N. (2014) “The Meaning of Management Information Systems and its Role in Telecommunication Companies in Yemen." American Journal of Software Engineering, vol. 2, no. 2 ,pp. 22-25.

[4] Al-Mamary ,Y., \& Shamsuddin,A., \& Aziati ,N. (2014) , "Factors Affecting Successful Adoption of Management Information Systems in Organizations towards Enhancing Organizational Performance." American Journal of Systems and Software, vol. 2, no. 5 ,pp. 121-126.

[5] Petter, S., DeLone, W., \& McLean, E. (2013). Information Systems Success: The Quest for the Independent Variables. Journal of Management Information Systems, Vol. 29, No. 4, pp. 7-61.

[6] Hasan,Y., \& Shamsuddin,A., \& Aziati ,N. (2013), The Impact of Management Information Systems adoption in Managerial Decision Making : A Review, The International Scientific Journal of Management Information Systems ,Vol.8 ,No.4,pp.010-017.

[7] Al-Mamary, Y., \& Shamsuddin,A., \& Aziati ,N. (2014) Key factors enhancing acceptance of management information systems in Yemeni companies, Journal of Business and Management Research, Volume. 5 , pp. 108-111.

[8] Petter ,S., \& DeLone, W., \& McLean,E. (2008). Measuring information systems success: models, dimensions, measures, and interrelationships. European Journal of Information Systems, vol.17,pp. 236263.

[9] Gen-Liang Z. (2012). Consumer acceptance of Internet as a channel of distribution. Journal of Business and Management Research, Vol. 1, pp. 20-27.

[10] Igbaria ,M., \& Zinatelli ,N., \& Zinatelli ,P., \& Cavaye, A. (1997) Personal Computing Acceptance Factors in Small Firms: A Structural Equation Model, MIS Quarteriy.

[11] Bechina, A.., \& Ndlela, M. (2007). Success Factors in Implementing Knowledge Based Systems, Electronic Journal of Knowledge Management, Volume 7 Issue 2, pp.211 - 218.

[12] Zhao, L. (2010). Study on Online Banking Adoption and Its Predictors. Second International Conference on Multimedia and Information Technology, pp.155-158.

[13] Brown, I. (2002). Individual and Technological Factors Affecting Perceived Ease of Use of Web-based Learning Technologies in a Developing Country ,EJISDC.

[14] Chuttur M. (2009). "Overview of the Technology Acceptance Model: Origins, Developments and Future Directions ," Indiana University, USA . Sprouts: Working Papers on Information Systems, Vol.9,No.37. 
[15] Sabherwal, R., \& Jeyaraj ,A. \&\& Chowa, C. (2006). Information System Success : Individual and Organizational Determinants, Management Science, Vol. 52, No. 12, pp. 1849-1864.

[16] Igbaria, M., \& Iivari, J. (1995). The Effects of Self-efficacy on Computer Usage, Omega, Int. J. Mgmt Sci. Vol. 23, No. 6, pp. 587-605.

[17] Nasri, W., \& Charfeddine , L. (2012). An Exploration of Facebook . Com Adoption in Tunisia Using Technology Acceptance Model and Theory of Reasoned Action , Interdisciplinary Journal of Contemporary Reserch in Business, Vol 4, No 5,pp. 948-969.

[18] Davis, F. (1989). Perceived usefulness, Perceived ease of use , and user acceptance of information technology. MIS Quarterly, 13,pp.319-340.

[19] Su ,Y-Y., \& Fulcher,J., \& Win ,K.. , \& Chiu,H-C, \& Chiu,G-F (2008). Evaluating the implementation of Electronic Medical Record (EMR) Systems from the Perspective of Health Professional, IEEE 8th International Conference on Computer and Information Technology Workshops, pp.589-594.

[20] Halawi ,L. , Mccarthy , R. ,\& Aronson, J. (2008) An Empirical Investigation of Knowledge Management Systems success ,Journal of Computer Information Systems ,pp. 121-136.

[21] Seddon ,P., \& Kiew ,M-Y. (1995). A partial test and development of delone and mclean's model of IS success , vol.4,no.1, pp.90-109.

[22] Palvia, P. (1996) A model and instrument for measuring small business user satisfaction with information technology, Information \& Management 31 ,pp.15 I-163.

[23] Nowduri1 \& Al-Dossary (2012). Management Information Systems and Its Support to Sustainable Small and Medium Enterprises International Journal of Business and Management; Vol. 7, No. 19,pp. 125-131.

[24] Belle, J-P. ,\& Eccles ,M., \& Nash ,J. (2001) Discovering Information Systems.

\section{Authors}

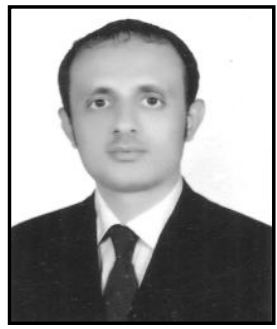

Yaser Hasan Salem Al-Mamary, Yaser Hasan Al-Mamary is a $\mathrm{PhD}$ student at University of Tune Hussein Onn Malaysia .He is from Yemen. He will receive his PhD degree from Faculty of Technology Management and Business. His research and publications focus on topics such as Management Information Systems (MIS), IS Success, Technology Management, Information Systems, and Technology Adoption.

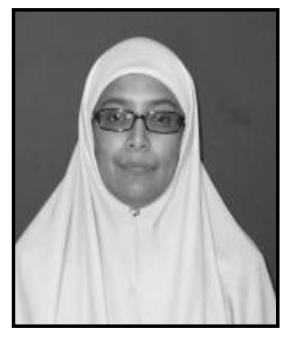

Associate. Prof. Dr Alina Binti Shamsuddin, is Head of the Department of Academic Programs (JPPA) Centre for Development and Academic Training UTHM. Her research and publications focus on technology management - supply chain management, Performance Measurement System, and Innovation Management.

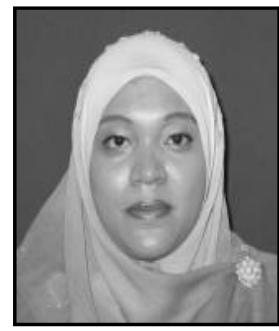

Dr. Nor Aziati BT Abdul Hamid, is Senior Lecturer at Faculty of Technology Management and Business UTHM. Her research and publications focus on IT Outsourcing, Knowledge Management, and Knowledge Transfer. 
International Journal of Energy, Information and Communications Vol.6, Issue 1 (2015) 